DOI: https://doi.org/10.15407/techned2019.06.088

\title{
HIGH-SPEED SECONDARY MEASURING TRANSDUCER FOR CAPACITIVE SENSORS WITH GROUNDED ELECTRODES
}

Journal

Publisher

ISSN

Issue

Pages
Tekhnichna elektrodynamika

Institute of Electrodynamics National Academy of Science of Ukraine 1607-7970 (print), 2218-1903 (online)

No 6, 2019 (November/December)

$88-92$

\section{Authors \\ P.I. Borshchov*, A.S. Levitskyi ${ }^{\star *}$ \\ Institute of Electrodynamics National Academy of Sciences of Ukraine, pr. Peremohy, 56, Kyiv, 03057, Ukraine, e-mail: pavbor2010@gmail.com \\ * ORCID ID : http://orcid.org/0000-0003-1363-9252 \\ ** ORCID ID : http://orcid.org/0000-0002-0146-9498}

\begin{abstract}
A new compensation bridge measuring transducer is proposed for operation with capacitive sensors having grounded electrodes. Two variants of its construction are described: with analog and with analog-digital balancing of charges on sensor capacitors. The advantages of the converter with analog-digital balancing are noted: compactness and improved speed. The research results of the error from the nonlinearity of the conversion characteristic of the experimental sample of the device are given. It is shown that the proposed converter provides a combination of high accuracy with a high conversion rate of informative parameters of capacitive sensors with grounded electrodes. References 9 , figures 3, table 1.
\end{abstract}

Key words: capacitive sensor, grounded electrode, compensation bridge measuring transducer, increase speed. 
Received: 21.03.2019

Accepted: 04.06.2019

Published: 25.10.2019

\section{References}

1. Levitskyi A.S. Methods and devices for automatic measurement of air gap in hydrogenerators. Hidroenerhetyka Ukrainy. 2007. No 4. Pp. 29-35. (Ukr)

2. Bernhard Roth. Method and apparatus for determining a capacitance and/or change in capacitance of a capacitive sensor element United States Patent No 2012/0092030. 2017.

3. CAV444 - C/V transmitter IC with adjustable output voltage for capacitive input signals. URL: https://www.analog-micro.com/_pages/ics/cav444/cav444-datasheet.pdf (accessed 15.02.2019).

4. Grinevych F.B., Novik A.I. Measuring compensatory and bridge devices with capacitive sensors. Kyiv: Naukova Dumka, 1987. 112 p. (Rus)

5. Novik A.I. Using the inverted function of the voltage divider to build a measuring transducer. Tekhnichna Elektrodynamika . 2006. No 3. Pp. 55-58. (Rus)

6. Borshchov P.I., Novik A.I. Capacitive distance meter to grounded surface. A.S. No 1536188 USSR. 1990. (Rus)

7. Dennis K. Briefer. Charge balance network with floating ground capacitive sensing. United States Patent No 6,316,948 B1. 2001.

8. AD7747. 24-Bit Capacitance-to-Digital Converter with Temperature Sensor (rev.0). URL: ht tp://www.analog.com/media/en/technical-documentation/data-sheets/AD7747.pdf (accessed 15.02.2019).

9. Nebolyubov E.Yu., Novik A.I. Electronic converters for work with capacitive sensors (analog and digital). Tekhnichna Elektrodynamika. 2015. No 3. Pp. 67-74. (Rus) 